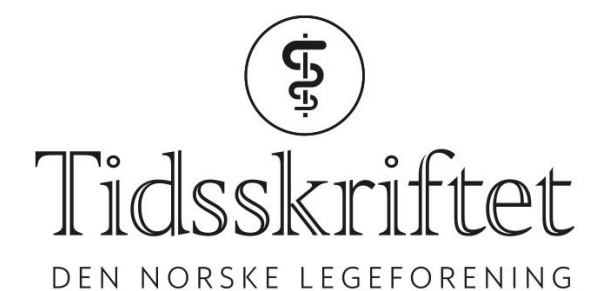

DEN NORSKE LEGEFORENING

\title{
Legen er mer enn medisinsk ekspert
}

ANMELDELSER

\section{IVAR SKJAK NORDRUM}

Studieprogramleder for profesjonsstudiet i medisin og professor i rettsmedisin, Fakultet for medisin og helsevitenskap

Norges teknisk-naturvitenskapelige universitet

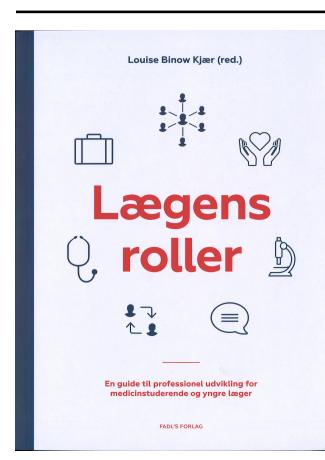

Louise Binow Kjærred.

Lægens roller

199 s, tab, ill. København: FADL's Forlag, 2017. Pris DKK зоo

ISBN 978-87-7749-902-9

Målgruppen er medisinstudenter og yngre leger i Danmark. Forfatterne diskuterer de rollene en lege har i tillegg til å være medisinsk ekspert, og boken er derfor tematisk forankret i den danske Sundhedsstyrelsens beskrivelse av «de 7 lægeroller» fra 2013 (1) og tradisjonen i land som Canada, USA og Storbritannia.

Boken er inspirert av redaktørens arbeid som leder av professionssporet (langsgående tema) ved medisinstudiet i Århus. Boken er lettlest, og teksten brytes fint opp av fakta-, case- og stop og tænk-bokser. Kapitlene avsluttes med «Take-home-message» og en litteraturliste.

De 11 kapitlene er forfattet av 18 forfattere, og boken er delt i to deler: Kjernekompetencer $i$ lagelig professionalisme og En god start på lagelivet. Den første delen har syv kapitler: At blive professionel som lage, Introduktion til sundheslovgivningen for lagestuderende, Klinisk etikk for lagestuderende, Patientcentreret kommunikation: Samtalens struktur og redskaper, Feedback og supervision, Lagen som leder og Lagen som forsker. Den andre delen består av de fire kapitlene Overgangen til lagelivet, Sundhesvcesenets organisation, politisk styring og finansiering, Lagen i det tverrfaglig samarbejde og Hva slags lage vil jeg vare? Ett par av kapitlene gjelder det danske samfunnet og er derfor mindre relevante for norske forhold.

Boken gir en kortfattet, helhetlig og god oversikt over det særlig viktige faktum at legen er så mye mer enn en medisinsk ekspert. Legen har også roller som leder, akademiker, 
helseopplyser, kommunikator og samarbeidspartner. Til sammen definerer dette den profesjonelle lege.

Jeg anbefaler boken fordi vi i norsk medisinerutdanning forholder oss til rolleforståelse på en mer usynlig og distansert måte, gjennom blant annet beskrivelse av læringsutbytter og læringsmål både i grunnutdanningen og i den nye spesialistutdanningen, og fordi vi ikke har en slik bok.

Selv om boken passer best for den danske målgruppen den er tiltenkt, vil både norske medisinstudenter, leger i spesialisering og alle som har roller i medisinsk utdanning, ha nytte av den.

\section{LITTERATUR:}

1. Lægers syv roller. København: Sundhedsstyrelsen, 2013.

https://www.sst.dk/da/nyheder/2013/laegers-syv-roller (16.10.2017).

Publisert: 22. januar 2018. Tidsskr Nor Legeforen. DOI: 10.4045/tidsskr.17.o911

(C) Tidsskrift for Den norske legeforening 2020. Lastet ned fra tidsskriftet.no 